\title{
Orchidftgra
}

Vol. 1, No. 1, Bulan Februari Tahun 2021

DOI: http://dx.doi.org/10.35138/orchidagro.v1.i1.258

\section{Pengaruh Populasi Ikan Lele Dan Jenis Media Tanam Terhadap Pertumbuhan Dan Hasil Tanaman Bayam (Amaranthus Sp.) Pada Sistem Akuaponik}

\author{
Ridwan, Hudaya Mulyana, Lia Sugiarti \\ Program Studi Agroteknologi Fakultas Pertanian Universitas Winaya Mukti \\ Email: cepridwan10@gmail.com
}

(Received: 04-01-21; Published: 20-02-21)

\begin{abstract}
This study aims to study the interaction between catfish populations and the type of growing media on the growth and yield of spinach (Amaranthus sp.) Cultivated by the aquaponics system. This research was conducted using an experimental method (experiment), from July to August 2020 in the experimental area of the PUSKOPAD complex, Tanjungsari District, Sumedang Regency. at an altitude of $850 \mathrm{~m}$ above sea level. The experimental design used was the Split Plot Design with the basic design of the RAK. Which consists of 2 factors with 2 repetitions. The first factor or mainplot is the catfish population $(i)$ which consists of 4 levels, namely: $(i 1)=0$ tails, $(\mathrm{i} 2)=10$ tails, $(\mathrm{i} 3)=20$ tails, $(\mathrm{i} 4)=30$ tails. The second factor or subplot is the type of planting medium $(\mathrm{m})$ which consists of 4 types, namely: $(\mathrm{ml})=$ Rockwool, $(\mathrm{m} 2)=$ Oyster mushroom waste, $(\mathrm{m} 3)=$ husk charcoal, $(m 4)=$ Pumice stone. Based on the results of experiments regarding the influence of catfish populations and the type of growing media on the growth and yield of spinach grown in the aquaponic system. That there was an interaction between the treatment of catfish populations and the type of planting medium on the parameters of the observation of plant height at 20 days after planting (DAS) and 30 DAS and leaf number at 10 DAS and 35 DAS. The use of pumice growing media is best used for the cultivation of spinach in an aquaponic system and a population of 20 catfish is sufficient to provide the nutrient needs needed by spinach plants.
\end{abstract}

Keywords: Aquaponics, Catfish Population, Planting Media

\begin{abstract}
ABSTRAK
Penelitian ini bertujuan untuk mempelajari interaksi antara populasi ikan lele dan jenis media tanam terhadap pertumbuhan dan hasil tanaman bayam (Amaranthus sp.) yang dibudidayakan dengan sistem akuaponik. Penelitian ini dilakukan dengan metode percobaan (eksperimen), dari bulan Juli sampai Agustus 2020 di lahan percobaan komplek PUSKOPAD Kecamatan Tanjungsari, Kabupaten Sumedang. pada ketinggian $850 \mathrm{~m}$ dpl. Rancangan percobaan yang digunakan adalah Split Plot Design dengan rancangan dasar RAK. Yang terdiri dari 2 faktor dengan 2 kali ulangan. faktor pertama atau mainplot yaitu populasi ikan lele (i) yang terdiri dari 4 taraf yaitu: $\left(i_{1}\right)=0$ Ekor, $\left(i_{2}\right)=10$ Ekor, $\left(i_{3}\right)=20$ Ekor, $\left(i_{4}\right)=30$ Ekor. Faktor kedua atau subplot yaitu Jenis media tanam $(\mathrm{m})$ yang terdiri dari 4 taraf jenis yaitu: $\left(\mathrm{m}_{1}\right)=$ Rockwool, $\left(\mathrm{m}_{2}\right)=$ Limbah jamur tiram, $\left(\mathrm{m}_{3}\right)=$ Arang sekam, $\left(\mathrm{m}_{4}\right)$ = Batu apung. Berdasarkan hasil percobaan mengenai pengaruh populasi lele dan jenis media tanam terhadap pertumbuhan dan hasil tanaman bayam yang ditanam pada system akuaponik. Bahwa terjadi interaksi antara perlakuan populasi lele dan jenis media tanam terhadap parameter pengamatan tinggi tanaman pada umur 20 hari setelah tanam (HST) dan 30 HST serta jumkag daun pada umur 10 HST dan 35 HST. Penggunaan media tanam batu apung paling baik digunakan untuk budidaya tanaman bayam pada system akuaponik dan populasi lele 20 ekor sudah cukup mampu memberikan kebutuhan unsur hara yang dibutuhkan tanaman bayam.
\end{abstract}

Kata Kunci: Aquaponik, Media Tanam, Populasi Lele. 


\section{PENDAHULUAN}

Indonesia merupakan negara yang menjadikan sektor pertanian sebagai sektor yang paling utama. Budidaya pertanian meliputi kegiatan untuk mengembangbiakan salah satu tanaman dengan nilai jual yang tinggi. Krisis lahan merupakan masalah yang dihadapi Indonesia, sehingga menyebabkan petani kesulitan melakukan budidaya tanaman. Penyebab dari krisis lahan ini adalah lahan pertanian yang beralih fungsi dari pertanian ke non pertanian (Setiawan, 2016).

Salah satu komoditas yang bernilai ekonomis dan memiliki kandungan gizi yang baik dan mudah dibudidayakan di Indonesia adalah bayam. Bayam mempunyai nilai ekonomis tinggi dan bermanfaat bagi tubuh manusia. Kebutuhan gizi semakin hari semakin bertambah seiring dengan pertambahanya jumlah penduduk, peningkatan usia, taraf hidup yang lebih baik, dan kesadaran akan pentingnya gizi dalam makanan sehari hari. Hal ini menyebabkan peningkatan permintaan produk hortikultura khususnya tanaman bayam sebagai konsumsi masyarakat setiap harinya. Hasil survei produksi tanaman sayuran dan buah-buahan di Indonesia menunjukan bahwa luas panen bayam mencapai 45.325 hektar dengan produksi sebesar 134.159 ton atau rata-rata 2.96 ton per hektar (Direktorat Jenderal Hortikultura, 2014).

Dengan demikian meningkatnya permintaan bayam, masyarakat dapat berupaya memenuhi kebutuhan konsumsi bayam dengan memproduksi bayam organik melalui sistem budidaya akuaponik. Teknologi akuaponik merupakan gabungan teknologi akuakultur dengan teknologi hidroponik dalam satu sistem untuk mengoptimalkan fungsi air dan ruang sebagai media pemeliharaan. Prinsip dasar yang bermanfaat bagi budidaya perairan adalah sisa pakan dan kotoran ikan yang berpotensi memperburuk kualitas air, akan dimanfaatkan sebagai pupuk bagi tanaman air (Nugroho et al., 2012).
Ikan lele adalah jenis ikan air tawar yang dapat tumbuh dan berkembang dengan baik karena ikan lele dapat dibudidayakan di lahan yang terbatas. Dalam pemeliharaan ikan lele, tentunya menghasilkan limbah air kolam yang berasal dari hasil metabolisme ikan dan sisa pakan yang terlarut, dimana limbah ini mengandung zat pencemar yang bersifat toksik bagi ikan. Biasanya pergantian air pada budidaya lele menyebabkan pencemaran lingkungan sehingga berdampak buruk untuk lingkungan sekitar. Namun air yang berasal dari limbah lele ini masih bisa digunakan untuk proses pembudidayaan sayuran. Salah satu upaya yang dapat dilakukan yaitu budidaya ikan yang terintegrasi dengan tanaman melalui sistem akuaponik (Marsela, 2018).

Komponen yang penting untuk diperhatikan dalam kegiatan budidaya dengan sistem akuaponik juga adalah media tanam. Media tanam akuaponik secara umum seperti arang sekam, rockwool, dan batu apung memberikan pengaruh sebagai filter air di dalam kolam terutama terhadap nitrat dan fosfat sisa perombakan pakan ikan. Ditambah dengan penggunaan tanaman maka akan membentuk sistem biofilter. Media tanam akan mempengaruhi penyerapan unsur hara yang di dapat dari limbah budidaya ikan, Agar sesuai dengan kebutuhan maka perlu diketahui media tanam yang tepat untuk mengoptimalkan penyerapan unsur hara (Firdaus et al., 2018).

Dalam penelitian Puri, Afany, dan Peniwiratri (2020) menyatakan ketersediaan hara, pertumbuhan tanaman dan pertumbuhan ikan paling baik ditunjukkan dengan kepadatan ikan 33 ekor/petak. Dan jumlah populasi ikan pada system mina padi sawah berpengaruh dalam meningkatkan pertumbuhan padi sawah varietas rojo lele khususnya pada tinggi tanaman, jumlah anakan, berat segar, dan berat kering tanaman. Hasil penelitian Wicuksana, Hastati, dan Arini (2013) menunjukkan bahwa system biofilter akuaponik memberikan hasil lebih baik 
dibandingkan dengan system konversional dapat meningkatkan performa produksi ikan lele. Dan kadar ammonia dalam system ini masih dalam kisaran yang layak untuk pembesaran ikan lele dumbo hingga minggu ke 8 .

Maka dari itu menurut pada pertimbangan dan data di atas dirasa perlu untuk melakukan penelitian mengenai jumlah ikan lele sebagai penyedia unsur hara dan jenis media tanam yang paling sesuai untuk budidaya tanaman bayam dengan sistem akuaponik pada ukuran

$60 \mathrm{~L}$ air.

\section{METODE PENELITIAN}

Penelitian ini dilakukan dengan metode percobaan (eksperimen), dari bulan Juli sampai Agustus 2020 di lahan percobaan komplek PUSKOPAD Kecamatan Tanjungsari, Kabupaten Sumedang. Ketinggian tempat percobaan adalah $850 \mathrm{~m}$ dpl permukaan laut. Bahan dan alat yang digunakan dalam percobaan ini antara lain, Benih ikan lele usia 3 bulan, benih tanaman bayam bersertifikat dari PT East West Seed Indonesia, air, pelet pakan ikan merek Hi Pro Vite $781-2$, limbah media jamur tiram, rockwool, arang sekam, batu apung, ember 80 $\mathrm{L}$, penggaris, timbangan, kawat, gelas plastik, solder listrik, alat tulis, kamera, selang.

$$
\text { Rancangan lingkungan yang }
$$

digunakan dalam percobaan ini adalah Split Plot Design dengan rancangan dasar RAK yang terdiri dari 2 faktor dengan 2 kali ulangan. faktor pertama adalah jumlah populasi ikan lele (I) dan faktor kedua adalah jenis media tanam (M), taraf perlakuan pada percobaan ini yaitu: faktor pertama populasi ikan (I): $i_{1}=$ tanpa ikan; $i_{2}=10$ ekor ikan lele;

Tabel 1. Pengaruh populasi lele dan media tanam terhadap tinggi tanaman 10, 15, 25 dan 35 HST.

\begin{tabular}{lcccc}
\hline \multirow{2}{*}{\multicolumn{1}{c}{ Perlakuan }} & \multicolumn{4}{c}{ Rata-Rata Tinggi Tanaman $(\mathrm{cm})$} \\
\cline { 2 - 5 } & $10 \mathrm{HST}$ & $15 \mathrm{HST}$ & $25 \mathrm{HST}$ & $35 \mathrm{HST}$ \\
\hline Ikan Lele (I) $\mathrm{i}_{1}$ (Kontrol) & $0,94 \mathrm{a}$ & $1,15 \mathrm{a}$ & $1,67 \mathrm{a}$ & $1,98 \mathrm{a}$ \\
$\mathrm{i}_{2}(10$ ikan Lele) & $1,37 \mathrm{ab}$ & $1,80 \mathrm{ab}$ & $4,32 \mathrm{~b}$ & $6,18 \mathrm{~b}$ \\
$\mathrm{i}_{3}$ (20 ikan lele) & $1,44 \mathrm{ab}$ & $1,86 \mathrm{ab}$ & $5,14 \mathrm{~b}$ & $8,09 \mathrm{c}$
\end{tabular}

$i_{3}=20$ ekor ikan lele; $i_{4}=30$ ekor ikan lele, faktor kedua jenis media tanam $(\mathrm{M}): \mathrm{m}_{1}=$ Rockwool; $\mathrm{m}_{2}=$ Limbah jamur tiram; $\mathrm{m}_{3}=$ Arang sekam; $\mathrm{m}_{4}=$ Batu apung.

Analisis data pengamatan yang digunakan adalah analisis ragam berdasarkan Split Plot Design. Data hasil pengamatan dianalisis menggunakan analisis ragam (ANOVA) uji F pada taraf 5\% untuk menduga adanya pengaruh perlakuan. Apabila diperoleh data yang berbeda nyata dilanjutkan dengan uji BNT pada taraf $5 \%$.

\section{HASIL}

\section{A. Pengamatan Penunjang}

Pengamatan penunjang dilaksanakn dengan melakukan pengamatan terhadap serangan hama dan penyakit serta bobot awal dan akhir lele. Selama percobaan dilaksanakan tidak ditemukan gejala penyakit yang menyerang tanaman bayam. Dan hanya ditemukan satu gejala serangan hama yaitu lalat penggorok daun (Liriomyza sp.). Gejala yang telah dilakukan penambahan bobot ikan lele paling tinggi adalah pada ikan lele yang hidup dengan populasi 10 ekor yaitu bertambah $45 \mathrm{~g}$ pada setiap ekornya. Kemudian disusul ikan yang hidup pada populasi 20 ekor yang bertambah $35 \mathrm{~g}$ pada setiap ekornya dan yang terakhir ikan lele yang hidup pada populasi 30 ekor yang bertambah 27 g pada setiap ekornya.

\section{B. Pengamatan Utama \\ 1. Tinggi Tanaman}

Hasil analisis statistik tinggi tanaman bayam dapat dilihat pada Tabel 1,2 dan 3 .

\section{HASIL DAN PEMBAHASAN}




\begin{tabular}{lcccc}
\hline \multirow{2}{*}{ Perlakuan } & \multicolumn{4}{c}{ Rata-Rata Tinggi Tanaman $(\mathrm{cm})$} \\
\cline { 2 - 5 } & $10 \mathrm{HST}$ & $15 \mathrm{HST}$ & $25 \mathrm{HST}$ & $35 \mathrm{HST}$ \\
\hline $\mathrm{i}_{4}($ 30 ikan lele) & $1,68 \mathrm{~b}$ & $2,42 \mathrm{~b}$ & $5,65 \mathrm{~b}$ & $8,41 \mathrm{c}$ \\
\hline Media (M) m (Rockwool) & $1,32 \mathrm{ab}$ & $1,48 \mathrm{a}$ & $4,18 \mathrm{ab}$ & $5,63 \mathrm{~b}$ \\
$\mathrm{~m}_{2}$ (Limbah Baglog) & $0,96 \mathrm{a}$ & $1,70 \mathrm{ab}$ & $2,56 \mathrm{a}$ & $3,74 \mathrm{a}$ \\
$\mathrm{m}_{3}$ (Arang sekam) & $1,86 \mathrm{~b}$ & $2,28 \mathrm{~b}$ & $5,32 \mathrm{~b}$ & $7,89 \mathrm{c}$ \\
$\mathrm{m}_{4}$ (Batu apung) & $1,29 \mathrm{ab}$ & $1,78 \mathrm{ab}$ & $4,72 \mathrm{~b}$ & $7,41 \mathrm{bc}$ \\
\hline
\end{tabular}

Keterangan: Angka rata-rata yang diikuti huruf yang sama berbeda tidak nyata berdasarkan uji BNT pada taraf $5 \%$.

Berdasarkan Tabel 1, menunjukan bahwa tidak terjadi interaksi antara perlakuan populasi ikan lele dan jenis media tanam terhadap pertumbuhan tinggi tanaman pada usia 10 HST, 15 HST, 25 HST dan 35 HST. Pada usia 10 dan 15 HST perlakuan $i_{1}$ (kontrol) menunjukan berbeda tidak nyata dengan perlakuan $i_{2}$ (10 ekor) dan $i_{3}$ (20 ekor), namun berbeda nyata dengan perlakuan $\mathrm{i}_{4}$ (30 ekor). Dan untuk perlakuan jumlah populasi lele pada usia 10, 15, 25 dan 35 HST populasi.
Lele $\mathrm{i}_{4} \quad(30$ ekor $)$ memberikan pengaruh perlakuan lebih baik untuk pertumbuhan tingi tanaman. Pada perlakuan jenis media tanam $\mathrm{m}_{3}$ (arang sekam) memberikan pengaruh lebih baik untuk pertumbuhan tinggi tanaman pada usia 10, 15, 25 dan 35 HST. Interaksi antara populasi ikan lele dan jenis media tanamam terjadi pada pengamatan tinggi tanaman usia 20 HST dan 30 HST. Hasil analisis tinggi tanaman 20 HST dapat dilih Pada Tabel 2.

Table 2. Pengaruh populasi lele dan media tanam terhadap tinggi tanaman pada umur 20 HST.

\begin{tabular}{|c|c|c|c|c|c|c|c|c|}
\hline \multirow{2}{*}{ Perlakuan } & \multicolumn{8}{|c|}{ Rata-Rata Tinggi Tanaman $(\mathrm{cm})$} \\
\hline & \multicolumn{2}{|c|}{$\begin{array}{c}\mathrm{m}_{1} \\
\text { (Rockwool) }\end{array}$} & \multicolumn{2}{|c|}{$\begin{array}{c}\mathrm{m}_{2} \\
\text { (Limbah baglog) }\end{array}$} & \multicolumn{2}{|c|}{$\begin{array}{c}\mathrm{m}_{3} \\
\text { (Arang sekam) }\end{array}$} & \multicolumn{2}{|c|}{$\begin{array}{c}\mathrm{m}_{4} \\
\text { (Batu apung) }\end{array}$} \\
\hline \multirow{2}{*}{$\mathrm{i}_{1}$ (Kontrol) } & 1,37 & $\mathrm{a}$ & 1,33 & $\mathrm{a}$ & 1,33 & $\mathrm{a}$ & 1,57 & $\mathrm{a}$ \\
\hline & A & & A & & A & & A & \\
\hline \multirow{2}{*}{$\mathrm{i}_{2}(10$ ekor ikan lele $)$} & 2,62 & $\mathrm{a}$ & 2,03 & $\mathrm{a}$ & 3,33 & b & 3,47 & $\mathrm{~b}$ \\
\hline & A & & A & & B & & B & \\
\hline \multirow{2}{*}{$\mathrm{i}_{3}(20$ ekor ikan lele $)$} & 2,66 & a & 2,78 & a & 3,88 & $\mathrm{~b}$ & 3,42 & $a b$ \\
\hline & A & & A & & B & & $\mathrm{AB}$ & \\
\hline \multirow{2}{*}{$\mathrm{i}_{4}(30$ ekor ikan lele) } & 2,3 & $\mathrm{a}$ & 2,62 & $\mathrm{a}$ & 5,88 & $\mathrm{c}$ & 4,22 & $\mathrm{~b}$ \\
\hline & $\mathrm{A}$ & & A & & $\mathrm{C}$ & & $\mathrm{B}$ & \\
\hline
\end{tabular}

Keterangan: Angka rata-rata yang diikuti huruf kecil (arah vertical) dan huruf kapital (arah horizontal) yang sama berbeda tidak nyata berdasarkan uji BNT pada taraf 5\%

Pada Tabel 2 yang menunjukan bahwa, perlakuan $i_{1}(0$ ekor $)$ berbeda tidak nyata pada semua perlakuan media, begitupun juga pada perlakuan $\mathrm{m}_{1}$ (Rockwool) dan $\mathrm{m} 2$ (Limbah baglog) yang menunjukan berbeda tidak nyata pada semua perlakuan populasi lele. dan kombinasi perlakuan $\mathrm{i}_{4}$ (30 ekor) dan $\mathrm{m}_{3}$ (arang sekam) memberikan pengaruh terbaik untuk pertumbuhan tinggi tanaman bayam pada usia $20 \mathrm{HST}$.

Tabel 3. Pengaruh populasi lele dan media tanam terhadap tinggi tanaman pada usia 30 HST.

\begin{tabular}{|c|c|c|c|c|}
\hline \multirow[b]{2}{*}{ Perlakuan } & \multicolumn{4}{|c|}{ Rata-Rata Tinggi Tanaman $(\mathrm{cm})$} \\
\hline & $\begin{array}{c}\mathrm{m}_{1} \\
\text { (Rockwool) }\end{array}$ & $\begin{array}{c}\mathrm{m}_{2} \\
\text { (Limbah baglog) }\end{array}$ & $\begin{array}{c}\mathrm{m}_{3} \\
\text { (Arang sekam) }\end{array}$ & $\begin{array}{c}\mathrm{m}_{4} \\
\text { (Batu apung) }\end{array}$ \\
\hline $\mathrm{i}_{1}$ (Kontrol) & 1,7 & $1,67 \quad a$ & $2,13 \quad a$ & 2,92 \\
\hline
\end{tabular}




\begin{tabular}{|c|c|c|c|c|c|c|c|c|}
\hline \multirow{3}{*}{$\mathrm{i}_{2}(10$ ekor ikan lele $)$} & A & & A & & A & & A & \\
\hline & 5,72 & b & 2,68 & $\mathrm{a}$ & 6,42 & b & 8,12 & b \\
\hline & A & & A & & B & & B & \\
\hline \multirow{2}{*}{$\mathrm{i}_{3}(20$ ekor ikan lele) } & 7,02 & b & 3,23 & $\mathrm{a}$ & 9,73 & bc & 8,82 & $\mathrm{~b}$ \\
\hline & $\mathrm{A}$ & & $\mathrm{A}$ & & C & & BC & \\
\hline \multirow{2}{*}{$\mathrm{i}_{4}(30$ ekor ikan lele) } & 5,45 & $\mathrm{~b}$ & 3,67 & $\mathrm{a}$ & 12,32 & $\mathrm{c}$ & 8,38 & $\mathrm{~b}$ \\
\hline & $\mathrm{A}$ & & A & & $\mathrm{C}$ & & $\mathrm{B}$ & \\
\hline
\end{tabular}

Keterangan: Angka rata-rata yang diikuti huruf kecil (arah vertical) dan huruf kapital (arah horizontal) yang sama berbeda tidak nyata berdasarkan uji BNT pada taraf 5\%

Interaksi antara kombinasi perlakuan populasi lele dan jenis media tanam pada tinggi tanaman usia 30 HST. Hasil analisisnya dapat dilihat pada Tabel 3 menunjukan bahwa perlakuan $i_{1}$ (0 ekor) memberikan pengaruh berbeda tidak nyata pada semua taraf perlakuan media. Sementara pada kombinasi perlakuan $\mathrm{i}_{2}$ (10ekor) pada $\mathrm{m}_{4}$ (batu apung) memberikan pengaruh perlakuan lebih baik. pada kombinasi perlakuan $\mathrm{i}_{3}$ (20 ekor) dan $\mathrm{i}_{4}$ (30 ekor) perlakua $\mathrm{m}_{2}$ (Limbah baglog) berbeda nyata dengan $m_{3}$ (arang sekam). Dan kombinasi perlakuan $\mathrm{m}_{3}$ (arang sekam) dan $\mathrm{i}_{4}$ (30 ekor) memberikan pengaruh perlakuan lebih baik untuk pertumbuhan tinggi tanaman pada usia 30 HST.

\section{Jumlah Daun}

Hasil analisis menunjukan bahwa terjadi interaksi antara perlakuan populasi lele dan jenis media tanam terhadap jumlah daun tanaman bayam pada usia 10 HST dan 35 HST. dan Tidak terjadi interaksi pada usia 15 HST, 20 HST, 25 HST dan 30 HST.

Tabel 4. Pengaruh populasi lele dan media tanam terhadap jumlah daun pada umur 15, 20, 25 dan 30 HST.

\begin{tabular}{lcccc}
\hline \multicolumn{1}{c}{ Perlakuan } & \multicolumn{4}{c}{ Rata-Rata Jumlah Daun } \\
& $15 \mathrm{HST}$ & $20 \mathrm{HST}$ & $25 \mathrm{HST}$ & $30 \mathrm{HST}$ \\
\hline Ikan Lele (I) & & & & \\
$\mathrm{i}_{1}$ (Kontrol) & $0,00 \mathrm{a}$ & $1,50 \mathrm{a}$ & $3,67 \mathrm{a}$ & $4,17 \mathrm{a}$ \\
$\mathrm{i}_{2}(10$ ikan lele) & $2,83 \mathrm{~b}$ & $4,17 \mathrm{~b}$ & $5,50 \mathrm{~b}$ & $6,17 \mathrm{~b}$ \\
$\mathrm{i}_{3}(20$ ikan lele) & $3,58 \mathrm{~b}$ & $5,33 \mathrm{~b}$ & $6,58 \mathrm{~b}$ & $7,50 \mathrm{~b}$ \\
$\mathrm{i}_{4}(30$ ikan lele) & $4,25 \mathrm{~b}$ & $6,08 \mathrm{~b}$ & $7,27 \mathrm{~b}$ & $8,58 \mathrm{~b}$ \\
\hline Media (M) & & & & \\
$\mathrm{m}_{1}$ (Rockwool) & $1,42 \mathrm{~b}$ & $2,50 \mathrm{~b}$ & $3,17 \mathrm{~b}$ & $4,29 \mathrm{~b}$ \\
$\mathrm{~m}_{2}$ (Limbah Baglog) & $0,67 \mathrm{a}$ & $1,17 \mathrm{a}$ & $1,25 \mathrm{a}$ & $1,63 \mathrm{a}$ \\
$\mathrm{m}_{3}$ (Arang Sekam) & $1,50 \mathrm{c}$ & $2,75 \mathrm{c}$ & $3,83 \mathrm{c}$ & $4,50 \mathrm{~d}$ \\
$\mathrm{~m}_{4}$ (Batu Apung) & $1,75 \mathrm{~d}$ & $2,13 \mathrm{~d}$ & $2,67 \mathrm{~d}$ & $2,79 \mathrm{c}$ \\
\hline
\end{tabular}

Keterangan: Angka rata-rata yang diikuti huruf kecil (arah vertical) dan huruf kapital (arah horizontal) yang sama berbeda tidak nyata berdasarkan uji BNT pada taraf 5\%.

Tabel 4. menunjukan data hasil analisis jumlah daun 15 HST, 20 HST, 25 HST dan 30 HST dimana pada perlakuan populasi lele $i_{1} \quad(0$ ekor $)$ memberikan pengaruh berbedanyata dengan perlakuan lainnya. Dan pada perlakuan media $\mathrm{m}_{4}$ (batu apung) menunjukan pengaruh terbaik terhadap pertumbuhan jumlah daun pada 15, 20 dan 25 HST, dan $m_{3}$ (Arang sekam) memberikan pengaruh terbaik pada $30 \mathrm{HST}$. Perlakuan $\mathrm{m}_{2}$ (limbah baglog) selalu berbeda nyata dengan perlakuan m1 (rockwool), $\mathrm{m}_{3}$ (arang sekam), $\mathrm{m}_{4}$ (batu apung) pada analisis jumlah daun usia 15, 20, 25 dan 30 HST. 
Tabel 5. Pengaruh populasi lele dan media tanam terhadap jumlah daun pada umur 10 HST.

\begin{tabular}{|c|c|c|c|c|c|c|c|c|}
\hline \multirow{3}{*}{ Perlakuan } & \multicolumn{8}{|c|}{ Rata-Rata Jumlah Daun } \\
\hline & \multicolumn{2}{|c|}{$\begin{array}{c}\mathrm{m}_{1} \\
\text { (Rockwool) }\end{array}$} & \multicolumn{2}{|c|}{$\begin{array}{c}\mathrm{m}_{2} \\
\text { (Limbah baglog) }\end{array}$} & \multicolumn{2}{|c|}{$\begin{array}{c}\mathrm{m}_{3} \\
\text { (Arang sekam) }\end{array}$} & \multicolumn{2}{|c|}{$\begin{array}{c}\mathrm{m}_{4} \\
\text { (Batu apung) }\end{array}$} \\
\hline & 0,00 & $\mathrm{a}$ & 0,00 & $\mathrm{a}$ & 0,00 & $\mathrm{a}$ & 0,50 & $\mathrm{a}$ \\
\hline & A & & A & & A & & B & \\
\hline \multirow{2}{*}{$\mathrm{i}_{2}(10$ ekor ikan lele) } & 1,00 & $\mathrm{~b}$ & 0,00 & $\mathrm{a}$ & 1,00 & $\mathrm{~b}$ & 1,00 & $\mathrm{a}$ \\
\hline & $\mathrm{B}$ & & A & & $\mathrm{B}$ & & B & \\
\hline \multirow{2}{*}{$\mathrm{i}_{3}(20$ ekor ikan lele $)$} & 1,00 & $\mathrm{~b}$ & 0,00 & $\mathrm{a}$ & 1,00 & $\mathrm{~b}$ & 1,00 & $\mathrm{a}$ \\
\hline & $\mathrm{B}$ & & $\mathrm{A}$ & & $\mathrm{B}$ & & $\mathrm{B}$ & \\
\hline \multirow{2}{*}{$\mathrm{i}_{4}(30$ ekor ikan lele $)$} & 1,00 & $\mathrm{~b}$ & 0,00 & $\mathrm{a}$ & 1,50 & $\mathrm{~b}$ & 1,00 & $\mathrm{a}$ \\
\hline & $\mathrm{B}$ & & A & & $\mathrm{B}$ & & B & \\
\hline
\end{tabular}

Keterangan: Angka rata-rata yang diikuti huruf kecil (arah vertical) dan huruf kapital (arah horizontal) yang sama berbeda tidak nyata berdasarkan uji BNT pada taraf 5\%.

Data hasil analisis jumlah daun usia 10

HST dapat dilihat pada tabel 5 yang menunjukan bahwa pada kombinasi perlakuan $\mathrm{i}_{1}$ (0 ekor) taraf $\mathrm{m}_{4}$ (batu apung) berbeda nyata dengan taraf $\mathrm{m}_{1}$ (rockwool), $\mathrm{m}_{2}$ (limbah baglog) dan $m_{3}$ (arang sekam). Dan pada kombinasi perlakuan $\mathrm{i}_{2}$ (10 ekor), $\mathrm{i}_{3}$ (20 ekor) dan $\mathrm{i}_{4}$ (30 ekor) perlakuan $\mathrm{m}_{2}$ (limbah baglog) berbeda nyata dengan perlakuan $\mathrm{m} 1$ (rockwool), $\mathrm{m}_{3}$ (limbah baglog) dan $\mathrm{m} 4$ (batu apung). Pada kombinasi perlakuan media tanam $\mathrm{m} 1$ (rockwool), dan $\mathrm{m}_{3}$ (arang sekam), perlakuan $i_{1}$ (0 ekor) berbeda nyata dengan perlakuan $i_{2}$ (10 ekor), $i_{3}$ (20 ekor) dan $i_{4}$ (30 ekor). Dan pada perlakuan media tanam $\mathrm{m}_{2}$ (limbah baglog) dan $\mathrm{m}_{4}$ (batu apung) menunjukan pengaruh berbeda tidak nyata pada semua perlakuan populasi lele.

Tabel 6. Pengaruh populasi lele dan media tanam terhadap jumlah daun pada usia 35 HST.

\begin{tabular}{lcccccccc}
\hline & \multicolumn{9}{c}{ Rata-Rata Jumlah Daun } & \multicolumn{2}{c}{$\mathrm{m}_{4}$} \\
& \multicolumn{2}{c}{$\mathrm{m}_{1}$} & \multicolumn{2}{c}{$\mathrm{m}_{2}$} & $\mathrm{~m}_{3}$ & \multicolumn{2}{c}{$\mathrm{m}_{4}$} \\
& Perlakuan & (Rockwool) & (Limbah baglog) & $\begin{array}{c}\text { (Arang } \\
\text { sekam) }\end{array}$ & \multicolumn{2}{c}{ (Batu apung) } \\
\hline $\mathrm{i}_{1}($ Kontrol) & 1,83 & $\mathrm{a}$ & 0,00 & $\mathrm{a}$ & 2,67 & $\mathrm{a}$ & 3,17 & $\mathrm{a}$ \\
& $\mathrm{B}$ & & $\mathrm{A}$ & & $\mathrm{C}$ & & $\mathrm{C}$ & \\
$\mathrm{i}_{2}(10$ ekor ikan lele) & 5,83 & $\mathrm{~b}$ & 1,83 & $\mathrm{~b}$ & 5,00 & $\mathrm{~b}$ & 5,50 & $\mathrm{~b}$ \\
& $\mathrm{~B}$ & & $\mathrm{~A}$ & & $\mathrm{~B}$ & & $\mathrm{~B}$ & \\
$\mathrm{i}_{3}(20$ ekor ikan lele) & 6,50 & $\mathrm{~b}$ & 2,83 & $\mathrm{bc}$ & 5,83 & $\mathrm{~b}$ & 6,17 & $\mathrm{~b}$ \\
& $\mathrm{~B}$ & & $\mathrm{~A}$ & & $\mathrm{~B}$ & & $\mathrm{~B}$ & \\
$\mathrm{i}_{4}(30$ ekor ikan lele) & 5,33 & $\mathrm{~b}$ & 3,50 & $\mathrm{c}$ & 6,67 & $\mathrm{~b}$ & 6,67 & $\mathrm{~b}$ \\
& $\mathrm{~B}$ & & $\mathrm{~A}$ & & $\mathrm{C}$ & & $\mathrm{B}$ & \\
\hline
\end{tabular}

Keterangan: Angka rata-rata yang diikuti huruf kecil (arah vertical) dan huruf kapital (arah horizontal) yang sama berbeda tidak nyata berdasarkan uji BNT pada taraf $5 \%$. 
Dan hasil analisis jumlah daun usia 35 HST dalap dilihat pada tabel 6. Tabel 6 menunjukan bahwa, pada perlakuan $\mathrm{i}_{1}$ ( 0 ekor) dan $\mathrm{i}_{4}$ (30 ekor) perlakuan $\mathrm{m}_{3}$ (arang sekam) dan $\mathrm{m}_{4}$ (batu apung) memberikan pengaruh lebih baik dan berbeda nyata dengan perlakuan $\mathrm{m}_{1}$ (rockwool) dan $\mathrm{m}_{2}$ (limbah baglog), sedangkan pada perlakuan populasi lele $\mathrm{i}_{2}$ (10 ekor) dan $\mathrm{i}_{3}$ (20 ekor), perlakuan media tanam m2 (limbah baglog), berbeda nyata dengan perlakuan $\mathrm{m}_{1}$ (rockwool), $\mathrm{m}_{3}$ (arang sekam) dan $\mathrm{m}_{4}$ (batu apung). Pada perlakuan media tanam $\mathrm{m} 1$ (rockwool), $\mathrm{m}_{2}$ (limbah baglog), $\mathrm{m}_{3}$ (arang sekam) dan $\mathrm{m}_{4}$ (batu apung) perlakuan populasi lele $\mathrm{i}_{1}$ ( 0 ekor) berbeda nyata dengan perlakuan $\mathrm{i}_{2}$ (10 ekor), $\mathrm{i}_{3}$ (20 ekor) dan $\mathrm{i}_{4}$ (30 ekor).

\section{Bobot Basah (gram)}

Hasil analisis lanjutan pengaruh populasi lele dan media tanam terhadap bobot basah tanaman bayam dapat dilihat pada Tabel 7 .

Tabel 7. Pengaruh populasi lele dan media tanam terhadap bobot basah tanaman bayam

\begin{tabular}{lc}
\hline \multicolumn{1}{c}{ Perlakuan } & $\begin{array}{c}\text { Rata-Rata Bobot } \\
\text { Basah }(\mathrm{g}) \\
35 \mathrm{HST}\end{array}$ \\
\hline Ikan Lele $(\mathrm{I})$ & \\
$\mathrm{i}_{1}$ (Kontrol) & $0,20 \mathrm{a}$ \\
$\mathrm{i}_{2}($ 10 ikan lele) & $1,02 \mathrm{~b}$ \\
$\mathrm{i}_{3}$ (20 ikan lele) & $1,31 \mathrm{bc}$ \\
$\mathrm{i}_{4}($ 30 ikan lele) & $1,41 \mathrm{c}$ \\
\hline Media $(\mathrm{M})$ & \\
$\mathrm{m}_{1}$ (Rockwool) & $0,90 \mathrm{~b}$ \\
$\mathrm{~m}_{2}$ (Limbah Baglog) & $0,23 \mathrm{a}$ \\
$\mathrm{m}_{3}$ (Arang Sekam) & $1,18 \mathrm{~b}$ \\
$\mathrm{~m}_{4}$ (Batu Apung) & $1,63 \mathrm{c}$ \\
\hline
\end{tabular}

Keterangan: Angka rata-rata yang diikuti huruf kecil (arah vertical) dan huruf kapital (arah horizontal) yang sama berbeda tidak nyata berdasarkan uji BNT pada taraf $5 \%$.

Tabel 7. menunjukan bahwa tidak terjadi interaksi antara perlakuan populasi lele dan jenis media tanam terhadap bobot basah tanaman. Pada perlakuan populasi ikan lele $i_{1}(0$ ekor $)$ berbeda nyata dengan perlakuan lainya dimana perlakuan $\mathrm{i}_{2}$ (10 ekor), $\mathrm{i}_{3}$ (20 ekor) dan $\mathrm{i}_{4}$ (30 ekor) berbeda tidak nyata satu sama lain. Pada perlakuan media tanam, Perlakuan $\mathrm{m}_{2}$ (limbah baglog) berbeda nyata dengan perlakuan $\mathrm{m} 1$ (rockwool), $\mathrm{m}_{3}$ (ara ng sekam) dan $\mathrm{m}_{4}$ (batu apung) di mana perlakuan $\mathrm{m}_{4}$ (batu apung) memberikan pengaruh perlakuan terbaik terhadap bobot basah tanaman bayam.

\section{Volume Akar (ml)}

Hasil analisis lanjutan pengaruh populasi lele dan media tanam terhadap volume akar tanaman bayam dapat dilihat pada Tabel 8 .

Tabel 8. Pengaruh populasi lele dan media tanam terhadap volume akar tanaman bayam

\begin{tabular}{lc}
\hline \multicolumn{1}{c}{ Perlakuan } & $\begin{array}{c}\text { Rata-Rata Bobot Basah } \\
(\mathrm{g}) \\
35 \mathrm{HST}\end{array}$ \\
\hline Ikan Lele (I) & $0,14 \mathrm{a}$ \\
$\mathrm{i}_{1}$ (Kontrol) & $0,47 \mathrm{~b}$ \\
$\mathrm{i}_{2}(10$ ikan lele) & $0,57 \mathrm{~b}$ \\
$\mathrm{i}_{3}(20$ ikan lele) & $0,55 \mathrm{~b}$ \\
$\mathrm{i}_{4}(30$ ikan lele) & \\
\hline Media $(\mathrm{M})$ & $0,40 \mathrm{a}$ \\
$\mathrm{m}_{1}$ (Rockwool) & $0,18 \mathrm{a}$ \\
$\mathrm{m}_{2}$ (Limbah & $0,41 \mathrm{a}$ \\
Baglog) & $0,74 \mathrm{~b}$ \\
$\mathrm{~m}_{3}$ (Arang Sekam) & \\
$\mathrm{m}_{4}$ (Batu Apung) & \\
\hline
\end{tabular}

Keterangan: Angka rata-rata yang diikuti huruf kecil (arah vertical) dan huruf kapital (arah horizontal) yang sama berbeda tidak nyata berdasarkan uji BNT pada taraf 5\%.

Hasil analisis yang di sajikan pada tabel 12 menunjukan bahwa tidak terjadi interaksi antara perlakuan populasi lele dan jenis media tanam terhadap volume akar tanaman. Pada perlakuan populasi ikan lele perlakuan $\mathrm{i}_{1}(0$ ekor $)$ berbeda nyata dengan perlakuan $\mathrm{i}_{2}$ (10 ekor), $\mathrm{i}_{3}$ (20 ekor) dan $\mathrm{i}_{4}$ (30 ekor) yang memberikan pengaruh lebih baik dibanding perlakuan i1 (0 ekor). Dan pada perlakuan media tanam, perlakuan $\mathrm{m}_{4}$ (batu apung) berbeda nyata 
denngan perlakuan $\mathrm{m} 1$ (rockwool), $\mathrm{m}_{2}$ (limbah baglog) dan m3 (arang sekam) dimana perlakuan $\mathrm{m}_{4}$ (batu apung) memberikan pengaruh lebih baik untuk pertumbuhan volume akar tanaman.

\section{PEMBAHASAN}

Hasil analisis menunjukan bahwa terjadi interaksi antara perlakuan populasi lele dan jenis media tanam terhadap parameter pengamatan tinggi tanaman usia 20 dan 30 HST serta jumlah daun pada usia 10 dan 35 HST. Namun tidak terjadi interaksi pada para meter pengamatan tinggi tanaman usia 10, 15, 25 dan 35 HST, jumlah daun usia 15, 20, 25 dan 30 HST, bobot basah serta volume akar tanaman bayam.

Tinggi tanaman bayam dipengaruhi oleh banyak faktor penentu yaitu faktor internal (hormon) dan lingkungan. Hormon yang mempengaruhi tinggi tanaman adalah auksin dan giberelin, sedangkan faktor lingkungan yang mempengaruhi pertambahan tinggi tanaman adalah unsur hara dan cahaya (Syaifudin et al., 2013). Air limbah dari kolam budidaya lele mengandung unsur hara yang dibutuhkan tanaman hal ini dikemukakan oleh Yuwono (2019), yang mengatakan bahwa air limbah kolam lele mengandung zat-zat yang diperlukan untuk pertumbuhan tanaman, diantaranya ada Corganik, nitrogen, phosphor dan kalium.

Dari hasil pengamatan dan analisis yang dilakukan pengaruh tinggi tanaman bayam yang paling baik diberikan oleh perlakuan populasi lele 20 dan 30 ekor pada media tanam arang sekam dan batu apung. Begitupun dengan pertumbuhan jumlah daun yang telah diamati dimana pengaruh perlakuan paling baik diberikan oleh perlakuan populasi lele 20 dan 30 ekor pada media tanam arang sekam dan batu apung. Tidak adanya perbedaan hasil antara perlakuan 20 ekor dan 30 ekor lele menunjukan bahwa populasi 20 ekor lele dalam ember dengan kapasitas 60 1/air sudah mampu memberikan supply kebutuhan unsur hara yang dibutuhkan oleh tanaman bayam untuk menunjang pertumbuhan tinggi dan jumlah daunnya. Sementara untuk bobot basah tanaman perlakuan 30 ekor lele dan media batu apung memberikan pengaruh paling baik untuk parameter pengamatan bobot basah tanaman. Dan untuk volume akar, perlakuan batu apung memberikan pengaruh terbaik untuk parameter pengamatan volume akar.

Media tanam arang sekam dan batu apung memiliki keistimewan di banding media rockwool dan limbah baglog dalam hal filtrasi penyerapan unsur hara. Arang sekam merupakan media tanam yang porous dan memiliki kandungan karbon (C) yang tinggi sehingga membuat media tanam ini menjadi gembur (Priono and Aziz, 2013). Arang sekam memiliki kandungan karbon sebanyak $41.02 \%$ (Fasya et al., 2017).

Kandungan karbon yang ada didalam media arang sekam sangat bermanfaat untuk penyerapan dan filtrasi ammonia sehingga dapat dimanfaatkan oleh tanaman sebagai unsur hara untuk menunjang pertumbuhan, karbon mempunyai pori-pori dalam jumlah besar dan adsorbsi akan terjadi karena adanya perbedaan energy potensial antara permukaan karbon dan zat yang diserap (Fasya et al., 2017).

Dan batu apung memberikan pengaruh lebih baik dibanding perlakuan yang lainnya dikarenakan media tanam batu apung dapat memengaruhi proses nitrifikasi karena bakteri nitrifikasi menggunakannya sebagai substrat untuk tempat hidupnya (Rakocy et al., 2005). Penggunaan batu apung dengan ukuran 2-3 mm juga sangat sesuai untuk menunjang pertumbuhan akar tanaman bayam dengan baik, karena media tanaman dengan ukuran tersebut mampu menahan biji bayam yang kecil untuk tidak lolos dan jatuh saat penanaman.

Selain itu media tanam arang sekam dan batu apung juga memberikan kondisi media yang lebih kering dan tidak terlalu basah sebagaimana rockwool dan limbah baglog jamur yang cenderung terlalu basah dan memadat bagi media tumbuh tanaman bayam. Pada parameter 
pengatamatan bobot basah dan volume akar tidak terjadi interaksi. Namun pada hasil efek mandiri menunjukan perlakuan populasi lele 20 dana 30 ekor serta penggunaan media batu apung memberikan pengaruh pertumbuhan paling baik bagi tanaman bayam.

\section{KESIMPULAN}

Berdasarkan hasil percobaan mengenai pengaruh populasi lele dan jenis media tanam terhadap pertumbuhan dan hasil tanaman bayam yang ditanama pada sistem akuaponik dapat disimpulkan bahwa terjadi interaksi antara perlakuan populasi lele dan jenis media tanam terhadap parameter pengamatan tinggi tanaman pada usia 20 dan 30 HST serta jumlah daun pada usia 10 dan 35 HST. Penggunaan media tanam batu apung paling baik digunakan untuk budidaya tanaman bayam pada sistem akuaponik. dan populasi lele 20 ekor sudah cukup mampu memberikan kebutuhan unsur hara yang dibutuhkan tanaman.

\section{SARAN}

Untuk budidaya tanaman dengan sistem akuaponik sebaiknya diperhatikan dalam memilih jenis tanaman dengan syarat tumbuh yang sesuai dengan keadaan sistem akuaponik. yaitu toleran dengan genangan air dan media yang cenderung basah. Pengunaan media arang sekam dan batu apung lebih di sarankan untuk digunakan dalam budidaya tanaman dengan sistem akuaponik.

\section{DAFTAR PUSTAKA}

Fasya, A.Z., N. Fadila, and I. Syafril. 2017. Pemanfaatan Arang Sekam Padi sebagai Adsorben Guna Mengurangi Limbah Cr. Final Proj.

Firdaus, M.R., Z. Hasan, I. Gumilar, and U. Subhan. 2018. Efektivitas Berbagai Media Tanam Untuk Mengurangi Karbon Organik Total Pada Sistem Akuaponik Dengan Tanaman Selada. J. Perikan. dan Kelaut.
11(1): $35-48$. http://jurnal.unpad.ac.id/jpk/article/view/18 220.

Hortikultura, D.J. 2014. Statistik Produksi Hortikultura Tahun 2014.

Marsela, F. 2018. Sistem Akuaponik Dengan Limbah Kolam Ikan Lele Untuk Memproduksi Sayuran Organik. 489(20). http://digilib.unila.ac.id/32389/.

Nugroho, R.A., L.T. Pambudi, D. Chilmawati, and H. Condro. 2012. Aplikasi Teknologi Aquaponic Pada Budidaya Ikan Air Tawar Untuk Optimalisasi Kapasitas Produksi. J. Saintek Perikan. 8(1): 46-51. doi: 10.14710/ijfst.8.1.46-51.

Priono, S.H., and S.A. Aziz. 2013. Pengaruh Komposisi Media Tanam Terhadap Pertumbuhan Stek Batang Tanaman Ara (Ficus carica L). Bogor.

Puri, R.A., M.R. Afany, and L. Peniwiratri. 2020. Pengaruh Populasi Ikan Nila Terhadap Ketersediaan Hara dan Pertumbuhan Tanaman Padi Sawah Pada Sistem Mina Padi di Dusun Biru, Desa Trihanggo, Kecamatan Gamping, Kabupaten Sleman, D.I Yogyakarta. J. TANAH DAN AIR (Soil Water Journal) 16(2): 85 . doi: 10.31315/jta.v16i2.3987.

Rakocy, J., R.L. Nelson, and G. Wilson. 2005. Aquaponic is the Combination of Aquaculture (Fish Farming) and Hydroponic (Growing Plants without Soil). Aquaponics J. 4(1): 8-11.

Setiawan, H.P. 2016. Alih Fungsi (Konversi) Lahan Pertanian Ke Non Pertanian Kasus di Kelurahan Simpang Pasir Kecamatan Palaran Kota Samarinda. eJournal Sosiatri/Sosiologi 4(2). https://ejournal.ps.fisipunmul.ac.id/site/?p=883. 
Syaifudin, A., E. Ratnasari, and Isnawati. 2013. Pengaruh pemberian berbagai konsentrasi kolkhisin terhadap pertumbuhan dan produksi tanaman cabai (Capsicum annum) varietas Lado F1. LenteraBio 2(2): 167171.

https://ejournal.unesa.ac.id/index.php/lente rabio/article/view/2603/1562.

Wicuksana, S.N., S. Hastati, and E. Arini. 2013. Journal of Aquaculture Management and Technology Journal of Aquaculture Management and Technology. J. Aquac. Manag. Technol. 2(3): 76-85. http://ejournal-

s1.undip.ac.id/index.php/jfpik.

Yuwono, B.B. 2019. Perbedaan Pertumbuhan Tanaman Kangkung (Ipomoea reptans Poir) Pada Perlakuan Air Leri Dan Air Limbah Kolam Lele Dengan Teknik Hidroponik Sebagai Media Pembelajaran Materi Pertumbuhan dan Perkembangan. 